\title{
EMISSION OF GREENHOUSE GASES AND ODORANTS FROM PIG SLURRY - EFFECT ON THE ENVIRONMENT AND METHODS OF ITS REDUCTION
}

\author{
EMISJA GAZÓW CIEPLARNIANYCH I ZWIĄZKÓW ODOROTWÓRCZYCH \\ Z GNOJOWICY ŚWIŃSKIEJ - WPŁYW NA ŚRODOWISKO NATURALNE \\ ORAZ SPOSOBY JEJ OGRANICZENIA
}

\begin{abstract}
Pig slurry is classified as a natural liquid fertilizer, which is a heterogeneous mixture of urine, faeces, remnants of feed and technological water, used to remove excrement and maintain the hygiene of livestock housing. The storage and distribution of pig slurry on farmland affect the environment as they are associated with, among others, the emission of various types of gaseous pollutants, mainly $\mathrm{CH}_{4}, \mathrm{CO}_{2}, \mathrm{~N}_{2} \mathrm{O}, \mathrm{NH}_{3}, \mathrm{H}_{2} \mathrm{~S}$, and other odorants. Methane $\left(\mathrm{CH}_{4}\right)$, carbon dioxide $\left(\mathrm{CO}_{2}\right)$ and nitrous oxide $\left(\mathrm{N}_{2} \mathrm{O}\right)$ are greenhouse gases $(\mathrm{GHGs})$ which contribute to climate change by increasing the greenhouse effect. Ammonia $\left(\mathrm{NH}_{3}\right)$ and hydrogen sulfide $\left(\mathrm{H}_{2} \mathrm{~S}\right)$ are malodorous gases responsible for the occurrence of odour nuisance which, due to their toxicity, may endanger the health and lives of humans and animals. $\mathrm{NH}_{3}$ also influences the increase of atmosphere and soil acidification. The article presents the environmental impact of greenhouse gases and odorous compounds emitted from pig slurry. Key gaseous atmospheric pollutants such as $\mathrm{NH}_{3}, \mathrm{H}_{2} \mathrm{~S}, \mathrm{CH}_{4}, \mathrm{CO}_{2}$ and $\mathrm{N}_{2} \mathrm{O}$ have been characterized. Furthermore, methods to reduce the emission of odours and GHGs from pig slurry during its storage and agricultural usage have been discussed.
\end{abstract}

Keywords: pig slurry, greenhouse gases (GHGs), odorous compounds, emission of gaseous pollutants, reduction of emission

\section{Introduction}

Intensive non-bedding pig farming leads to the formation of large quantities of waste in the form of slurry which is a liquid heterogeneous mixture of animal excrement (the urine to faeces ratio is approximately 60 to $40 \%$ ), undigested food residues, and water used for hygienic and cleaning purposes in livestock buildings [1,2]. Typical pig slurry is characterized by slightly alkaline reaction, high specific conductivity, as well as a high content of suspended solids and organic substances. Pig slurry contains an average of 6-8 \% dry matter and is affluent in mineral components easily digestible for plants, i.e. nitrogen,

\footnotetext{
${ }^{1}$ Faculty of Chemical Engineering and Technology, Cracow University of Technology, ul. Warszawska 24, 31-155 Kraków, Poland, phone +48 126282640

${ }^{2}$ Mineral and Energy Economy Research Institute, Polish Academy of Sciences, ul. J. Wybickiego 7 , 31-261 Kraków, Poland

*Corresponding author: martamarszalek@indy.chemia.pk.edu.pl
} 
phosphorus, potassium, calcium, magnesium, and sodium. It is also rich in trace elements: iron, cobalt, boron, zinc, manganese, copper, molybdenum, selenium, while the amount of heavy metals (lead, cadmium, mercury, arsenic) that it contains generally does not pose a risk to the soil environment $[2,3]$. Microbiological properties of pig slurry are determined by the presence of bacteria (microorganisms from the Enterobacteriaceae family and Streptococcus genus are dominant), viruses (e.g. rotavirus A, Aujeszky's disease virus), fungi, as well as eggs and oocysts of gastro-intestinal parasites (e.g. Ascaris, Trichuris) [2]. In legal terms, i.e. according to the Fertilizers and Fertilizing Act of 10 July 2007 [4], pig slurry is a natural fertilizer intended for agricultural application, and therefore the most appropriate way of its management should be using it to fertilize arable lands. However, due to the limited number of agronomic application dates of pig slurry (from 1 March to 30 November) [5] and its dose limits (170 kg of nitrogen in a pure ingredient per 1 hectare of farmland per year) $[4,6]$, in areas where large-scale pig fattening farms are located and where there is a shortage of farmland on which pig slurry can be applied, it is not possible to totally utilize the resulting pig slurry, and thereby its surplus must be stored [7].

The storage and distribution of pig slurry on agricultural lands both affect the environment as they are associated with, among others, the emission of various types of gaseous pollutants (greenhouse gases and odorous compounds). Pig slurry may contribute to climate change, being the source of methane, carbon dioxide and nitrous oxide emissions. These gases cause the greenhouse effect by trapping the infrared radiation and its subsequent emission as reverse thermal radiation, which leads to the increase of temperature on the Earth surface [8-10]. Rural areas also struggle with specific challenges concerning air quality. In areas where we have to deal with intensive non-bedding pig farming atmospheric pollution with odorants emitted from fields sprayed with pig slurry, from slurry tanks and livestock buildings is present. Malodorous compounds cause the formation of unpleasant and onerous odours which are the reason for inconvenience for the local communities living in areas adjacent to the farms. They can also trigger a large number of diseases such as ailments of the respiratory system (rhinitis, bronchitis, pneumonia, asthma), skin infections, allergies, headaches, migraines, or states of nervous irritation $[8,11-14]$.

\section{Emission of greenhouse gases from pig slurry and methods of its reduction}

Considerable amounts of $\mathrm{CO}_{2}, \mathrm{CH}_{4}$ and $\mathrm{N}_{2} \mathrm{O}$ are emitted during pig slurry storage and application on arable land. The greatest influence on emissions of the greenhouse gases (GHGs) from pig slurry have environmental factors and management practices [8-10, 15, 16].

Carbon dioxide is a key greenhouse gas, its global warming potential (GWP) by definition is 1 [17]. $\mathrm{CO}_{2}$ emitted from pig slurry is generated during putrefaction and fermentation processes (aerobic and anaerobic decomposition of organic substances) taking place in pig slurry, as well as during the hydrolysis of urea. A source of $\mathrm{CO}_{2}$ in piggeries, apart from slurry, are also animal respiration processes [10, 18-21]. Its permissible concentration in livestock buildings amounts to $3000 \mathrm{ppm}$ [22]. Elevated concentration of $\mathrm{CO}_{2}$ reduces the frequency and increases the depth of respiration in animals, while long-lasting and excessive concentration of $\mathrm{CO}_{2}$ leads to metabolic disorders or even acidosis [23]. 
Methane is the most abundant organic gas in the atmosphere and the predominant greenhouse gas emitted from slurry storage facilities, its GWP (for a period of 100 years) is 28 times higher than that of $\mathrm{CO}_{2}[17,24] . \mathrm{CH}_{4}$ released from pig slurry is produced by the anaerobic decomposition of organic matter by bacteria. This process takes place mainly $(65-75 \%)$ during the storage of pig slurry, but may also occur after its application on the fields. $\mathrm{CH}_{4}$ present in pig facilities is also generated as a result of bacterial fermentation in the pig large intestine. $\mathrm{CH}_{4}$ emission from pig slurry during its storage is favoured by anaerobic conditions, temperature increase $\left(25-35^{\circ} \mathrm{C}\right)$, low oxidation-reduction potential, neutral reaction, $\mathrm{C}: \mathrm{N}$ ratio in the range of $15-30$, and a high content of organic substances. The factor limiting the release of $\mathrm{CH}_{4}$ from pig slurry is the presence of ammonium ions and sulfides. The average daily amount of $\mathrm{CH}_{4}$ emission from $1 \mathrm{~m}^{3}$ of pig slurry varies from a few to as much as $100 \mathrm{~g}[8-10,16,19-21,25]$.

Nitrous oxide is a greenhouse gas with a very high GWP (which for the period of 100 years is 265 times higher than for $\mathrm{CO}_{2}$ ) and a very long lifetime in the atmosphere, which greatly contributes to the greenhouse effect $[17,26,27] . \mathrm{N}_{2} \mathrm{O}$ also contributes to the destruction of the ozone shield $[20,26] . \mathrm{N}_{2} \mathrm{O}$ emission from the stored slurry is negligible (emissions are chiefly caused by crust formation at the surface of the slurry) and comes mainly from the soil fertilized with the slurry since this gas is one of the intermediates of denitrification process (formation of nitrogen gas from nitrate reduction). It is also released during nitrification (transformation of ammonium to nitrate). The factors affecting the level of $\mathrm{N}_{2} \mathrm{O}$ are: the composition of pig slurry and the technique of its application on farmland, soil type, moisture, temperature, $\mathrm{pH}$ and the availability of soluble organic matter as well as weather conditions. Increased $\mathrm{N}_{2} \mathrm{O}$ emissions can also occur during composting, aeration, or aerobic treatment of pig slurry [10, 18, 20, 25, 27-30].

Pig production accounts for $13 \%$ of global greenhouse gas emissions from livestock sector, making it the second contributor of GHGs from this sector. The reduction of greenhouse gas emissions from pig breeding will help to minimize their impact on climate change $[15,16,20]$. The document which postulates lower GHG emissions in the European Union is Decision No 406/2009/EC of The European Parliament and of The Council of 23 April 2009 on the effort of Member States to reduce their greenhouse gas emissions by 2020 by $30 \%$ in comparison to 1990, which also proposes further joint reduction of GHG emissions by 2050 by $60-80 \%$ compared to 1990 [31].

The reduction of GHG emissions from pig slurry can be achieved by various methods. In the first place, rational nutrition of pigs should be ensured. Feeding animals with fodder characterized by a decreased content of crude protein promotes the reduction of $\mathrm{CH}_{4}$ and $\mathrm{N}_{2} \mathrm{O}$ emission from pig slurry, while the reduction of crude fibre content in feed rations for pigs lowers the $\mathrm{CH}_{4}$ emission [8, 20,29].

The release of GHGs from pig slurry in livestock buildings can be reduced by rapid faeces removal from both the floor and the piggery, appropriately frequent pit flushing, avoiding high temperature in animal housing as well as the use of biofilters $[8,20,25,29$, 32]. Haeussermann et al. [25] found that pig slurry removal, after each fattening period, combined with a complete cleaning of the slurry channels reduces the mean $\mathrm{CH}_{4}$ emission rate per animal per year by $40 \%$ in comparison to the pig slurry removal without cleaning the slurry pits [25].

At the stage of storage, an effective way of lowering the GHG emissions from pig slurry is the storage of slurry in hermetically sealed tanks or in tanks equipped with a special covers, e.g. plastic film cover or combinations of lightweight expanded clay 
aggregate with lactic acid (common cover materials like straw can increase emissions of methane and nitrous oxide), preferably at a temperature below $15{ }^{\circ} \mathrm{C}$ (an experiment conducted in a commercial piggery, emptied of pigs showed that increasing the temperature of slurry from 15 to $20^{\circ} \mathrm{C}$ results in doubling of $\mathrm{CO}_{2}$ emissions), and mixing the slurry just before emptying the tank [20, 24, 25, 29, 33]. Berg et al. [24] showed that combinations of cover materials (perlite, lightweight expanded clay aggregate or chopped straw) and acidification (using lactic acid) of pig slurry reduces $\mathrm{CH}_{4}$ and $\mathrm{N}_{2} \mathrm{O}$ emissions during storage effectively [24].

Operations which reduce GHG emissions from pig slurry during its storage and applying into the soil are: acidification, separation into solid and liquid fractions (however, some authors observed increased emissions after separation of pig slurry into fractions), anaerobic digestion (promotes anoxic processes and biogas (rich in $\mathrm{CO}_{2}$ and $\mathrm{CH}_{4}$ ) production, which can be used for electricity and heat production) and aeration (pig slurry aeration lowers $\mathrm{CH}_{4}$ and $\mathrm{CO}_{2}$ emissions while increasing $\mathrm{N}_{2} \mathrm{O}$ emission; however, the total effect of GHG emissions is lower in comparison to emissions from pig slurry not subjected to aeration) $[8,16,20,25,29,32-35]$. Bertora et al. [35] concluded that the separation of pig slurry reduces the $\mathrm{N}_{2} \mathrm{O}$ emissions with respect to the non-separated slurry. They estimated that amending the soil with $100 \mathrm{~kg}$ of slurry produces around $18.7 \mathrm{~g}$ of $\mathrm{N}_{2} \mathrm{O}-\mathrm{N}$ in 58 days, while separating the slurry and applying to the soil the two resulting solid and liquid fractions produces around $8.1 \mathrm{~g}$ of $\mathrm{N}_{2} \mathrm{O}-\mathrm{N}$ [35]. Fangueiro et al. [32] found that pig slurry acidification followed by solid/liquid separation may be an effective solution in terms of reducing emissions of $\mathrm{N}_{2} \mathrm{O}$ (by more than $30 \%$ ) and $\mathrm{CO}_{2}$ after soil application of the resulting fractions [32].

The reduction of $\mathrm{CH}_{4}$ release from pig slurry can also be achieved by the addition of humic acids (reduction of $\mathrm{CH}_{4}$ emissions by $34 \%$ by improving methanotrophic bacteria) or tannins from quebracho trees (reduction of $\mathrm{CH}_{4}$ emissions by up to $95 \%$ due to the noxious effects of these compounds on methanogens) [20], while that of $\mathrm{N}_{2} \mathrm{O}$ by spring application of pig slurry on the fields, surface application of pig slurry (e.g. using trailing hoses) and rapid soil incorporation (injection of slurry increases $\mathrm{N}_{2} \mathrm{O}$ emissions from agricultural soils), as well as fertilization with pig slurry subjected to separation into fractions or acidification followed by separation into fractions or acidified liquid fraction of pig slurry [29, 32-36].

\section{Emission of odorous substances from pig slurry and methods of its reduction}

More than 400 volatile organic and inorganic compounds with a high odour nuisance which are formed as a result of chemical and enzymatic reactions and microbial activity are emitted from pig slurry. The identified substances may include: alcohols, amines, aldehydes, ketones, carboxylic acids, esters, terpenes, organic sulfides, aromatic compounds (phenols, indoles, toluene, pyridine), $\mathrm{H}_{2} \mathrm{~S}$ and $\mathrm{NH}_{3}$ [37-40]. Odour-generating compounds are generally the end or intermediate products of fermentative degradation of substances contained in faeces and urine (mainly of proteins and fermentable carbohydrates) by anaerobic bacteria. As a result of protein degradation odorants are generated which, according to the scientific literature concerning pig slurry, are classified into four main groups of chemical compounds: volatile fatty acids, indoles and phenols, ammonia and volatile amines, and volatile sulfur-containing compounds (Table 1). 
However, carbohydrate degradation results mainly in the formation of volatile fatty acids with straight carbon chain $[9,12,37-40]$.

Classification of odorants released from pig slurry as a result of protein degradation [38]

\begin{tabular}{|c|c|c|c|}
\hline Odorant group & $\begin{array}{l}\text { Examples } \\
\text { of odorants }\end{array}$ & \begin{tabular}{|c|} 
Type of bacteria responsible for \\
the formation of a given group \\
of odorants
\end{tabular} & $\begin{array}{c}\text { The most important } \\
\text { decomposition process resulting } \\
\text { in a given group of odorants }\end{array}$ \\
\hline Volatile fatty acids & $\begin{array}{c}\text { acetic acid, } \\
\text { propionic acid, } \\
\text { butyric acid, } \\
\text { isobutyric acid, } \\
\text { valeric acid, } \\
\text { isovaleric acid, } \\
\text { caproic acid, } \\
\text { capric acid }\end{array}$ & $\begin{array}{c}\text { Streptococcus, } \\
\text { Peptostreptococcus, Eubacterium, } \\
\text { Lactobacillus, Escherichia, } \\
\text { Clostridium, Propionibacterium, } \\
\text { Bacteroides, Megasphaera }\end{array}$ & deamination of amino acids \\
\hline Indoles and phenols & $\begin{array}{l}\text { indole, } \\
\text { skatole, } \\
\text { cresol, } \\
\text { 4-ethylphenol } \\
\end{array}$ & $\begin{array}{l}\text { Propionibacterium, Escherichia, } \\
\text { Eubacterium, Clostridium }\end{array}$ & $\begin{array}{l}\text { decomposition of tyrosine, } \\
\text { phenylalanine and tryptophan }\end{array}$ \\
\hline $\begin{array}{l}\text { Ammonia and } \\
\text { volatile amines }\end{array}$ & $\begin{array}{l}\text { ammonia, } \\
\text { putrescine, } \\
\text { cadaverine, } \\
\text { methylamine, } \\
\text { ethylamine }\end{array}$ & $\begin{array}{c}\text { Streptococcus, } \\
\text { Peptostreptococcus, Bacteroides }\end{array}$ & $\begin{array}{c}\text { decomposition of urea, } \\
\text { decarboxylation of amino acids }\end{array}$ \\
\hline $\begin{array}{l}\text { Volatile } \\
\text { sulfur-containing } \\
\text { compounds }\end{array}$ & $\begin{array}{l}\text { sulfides, } \\
\text { methanethiol, } \\
\text { ethanethiol }\end{array}$ & Megasphaera & $\begin{array}{l}\text { sulfates reduction, decomposition of } \\
\text { sulfur-containing amino acids }\end{array}$ \\
\hline
\end{tabular}

Table 2

Genus of bacteria present in pig excrement and examples of odour-generating compounds produced by them during the decomposition of substances contained in faeces and urine [38]

\begin{tabular}{|c|c|}
\hline Genus of bacteria & Examples of odorous compouds \\
\hline Streptococcus & formic acid, acetic acid, propanoic acid, butanoic acid, ammonia, volatile amines \\
\hline Peptostreptococcus & $\begin{array}{l}\text { formic acid, acetic acid, propanoic acid, butanoic acid, } \\
\text { 2-methylpropanoic acid, pentanoic acid, hexanoic acid, } \\
\text { 3-methylbutanoic acid, 4-methylpentanoic acid, ammonia, volatile amines }\end{array}$ \\
\hline Eubacterium & $\begin{array}{l}\text { formic acid, acetic acid, propanoic acid, butanoic acid, } \\
\text { 2-methylpropanoic acid, pentanoic acid, hexanoic acid, } \\
\text { 3-methylbutanoic acid, 4-methylpentanoic acid, indoles and phenols }\end{array}$ \\
\hline Lactobacillus & formic acid, acetic acid, propanoic acid, butanoic acid \\
\hline Escherichia & formic acid, acetic acid, propanoic acid, butanoic acid \\
\hline Clostridium & $\begin{array}{l}\text { formic acid, acetic acid, propanoic acid, butanoic acid, } \\
\text { 2-methylpropanoic acid, pentanoic acid, hexanoic acid, } \\
\text { 3-methylbutanoic acid, indoles and phenols }\end{array}$ \\
\hline Propionibacterium & $\begin{array}{l}\text { formic acid, acetic acid, propanoic acid, butanoic acid, } \\
\text { 2-methylpropanoic acid, pentanoic acid, hexanoic acid, } \\
\text { 3-methylbutanoic acid, indoles and phenols }\end{array}$ \\
\hline Bacteroides & $\begin{array}{c}\text { formic acid, acetic acid, propanoic acid, butanoic acid, } \\
\text { 2-methylpropanoic acid, pentanoic acid, hexanoic acid, } \\
\text { 3-methylbutanoic acid, 4-methylpentanoic acid, ammonia, volatile amines }\end{array}$ \\
\hline Megasphaera & $\begin{array}{l}\text { formic acid, acetic acid, propanoic acid, butanoic acid, } \\
\text { 2-methylpropanoic acid, pentanoic acid, hexanoic acid, } \\
\text { 3-methylbutanoic acid, 4-methylpentanoic acid, volatile } \\
\text { sulfur-containing compounds }\end{array}$ \\
\hline
\end{tabular}


Odour formation is a complex process involving different bacterial species and a wide range of chemical compounds released during the anaerobic digestion (Table 2). A type of odorant being formed depends on many factors, primarily on the conditions of slurry storage and the diet of animals. According to studies by many authors the main compounds responsible for the high intensity of pig slurry unpleasant smell are: $p$-cresol, skatole, 4-ethylphenol, 4-methylphenol, acetic acid, $\mathrm{NH}_{3}, \mathrm{H}_{2} \mathrm{~S}$, dimethyl sulfide, dimethyl disulfide, and dimethyl trisulfide [9, 12, 37-40].

The key odorant emitted from pig slurry which pollutes the air and can pose a great risk to health as well as animal and human life is $\mathrm{NH}_{3}$. This gas has got a characteristic (pungent, irritating and unpleasant) scent and can already be felt in very low concentrations. The low $\mathrm{NH}_{3}$ concentration is sometimes the reason for odour nuisance (odour threshold of approximately $5 \mathrm{ppm}$ ), at higher concentrations $\mathrm{NH}_{3}$ causes irritation of mucous membranes, coughing fits, breathing disorders, or even death. When it comes to pigs, the primary response to the excess of $\mathrm{NH}_{3}$ is increased susceptibility to respiratory ailments and infections. This gas may contribute to a significant decline in animal productivity as well as animals' death [9, 11, 41-44].

$\mathrm{NH}_{3}$ is not only an odorant but also the main factor determining an increase in the acidification of atmosphere and soil. $\mathrm{NH}_{3}$ emitted from terrestrial ecosystems returns to the Earth's surface with dry and wet atmospheric precipitation causing disturbances of the nitrogen cycle in the environment, thereby contributing to soil acidification and eutrophication of surface waters [9, 18, 41-46]. The main source of $\mathrm{NH}_{3}$ emission is agriculture, especially animal husbandry, whose share in the global $\mathrm{NH}_{3}$ emissions from land-based sources is approximately $64 \%$. Pig production accounts for about $15 \%$ of global $\mathrm{NH}_{3}$ emission from animal husbandry [41]. In Poland about $98 \%$ of $\mathrm{NH}_{3}$ emission comes from agriculture, wherein livestock faeces account for around $69 \%$ of this emission [47].

$\mathrm{NH}_{3}$ emitted from pig slurry is the product of bacterial degradation of nitrogen compounds contained in it. The largest quantities of $\mathrm{NH}_{3}$ are produced by decomposition of urea present in animals' urine catalyzed by the urease enzyme which is characterized by a very fast hydrolyzing activity and produced by microorganisms present in faeces. $\mathrm{NH}_{3}$ is also generated as a result of microbial degradation of proteins found in the feces, however, this process proceeds very slowly, therefore the $\mathrm{NH}_{3}$ emission from faeces can play a more important role when the slurry is stored for many months. The total $\mathrm{NH}_{3}$ emission from pig slurry consists of partial emissions of this compound from pig slurry located in livestock housing and storage tanks, as well as from soils fertilized with slurry [41-43].

The content of nitrogen compounds in pig slurry, the size of the surface covered with the slurry, the temperature and $\mathrm{pH}$ of the slurry, as well as the velocity of airflow over its surface affect the level of $\mathrm{NH}_{3}$ emission from pig slurry present in husbandry facilities. The amount of $\mathrm{NH}_{3}$ released into the atmosphere during pig slurry storage depends on the composition of the slurry, time and conditions (temperature, frequency of stirring) of its storage, and construction (type of material, tightness) and parameters (capacity) of the tank. The size of $\mathrm{NH}_{3}$ emission from slurry while it is applied onto agricultural land is dependent upon the content of dry matter and $\mathrm{NH}_{3}$ nitrogen in the slurry, weather conditions (sunshine, wind speed, rain), the seasons, the type of soil and its humidity, the type of crop, as well as doses of pig slurry and ways of its distribution (surface broadcasting, band application, direct injection) $[18,41,43,46]$. 
The need to reduce $\mathrm{NH}_{3}$ emission from pig slurry results not only from ecological reasons and concerns about humans' and animals' health but also from the existence of a number of Polish [22, 48] and EU legal acts defining the permissible concentrations of $\mathrm{NH}_{3}$ in the environment, the workplace and buildings for livestock. The Regulation of the Minister of Agriculture and Rural Development dated 15 February 2010 [22] concludes that the $\mathrm{NH}_{3}$ concentration should not exceed $20 \mathrm{ppm}$ in facilities in which pigs are kept [22]. Furthermore, the Threshold Limit Value (TLV) of $\mathrm{NH}_{3}$ to which workers may be exposed during an 8-hour workday and average weekly working time over their whole working life, without any adverse effects on their health (also when retired) or that of next generations is $14 \mathrm{mg} / \mathrm{m}^{3}$ [48]. Another very important reason for limiting $\mathrm{NH}_{3}$ emission from pig slurry is the reduction of losses of nitrogen as a fertilizer component. The lost $\mathrm{NH}_{3}$ lowers the fertilizing value of pig slurry and thus increases the financial outlays incurred for the purchase of mineral fertilizers. The deficiency of nitrogen in the soil, one of the most important macronutrients, results in the deterioration of quality and decrease in crop yields, therefore this element must be supplemented by fertilization with compound or nitrogen fertilizers which generates additional costs [3, 41, 43].

The other odorant emitted from pig slurry, specially unpleasant and harmful to humans and animals, is $\mathrm{H}_{2} \mathrm{~S}$. This gas has a strong characteristic smell of rotten eggs and is perceptible at very low concentrations. Moreover, it is highly toxic, readily absorbed into the body through the lungs, and to a small extent through the skin. $\mathrm{H}_{2} \mathrm{~S}$ emitted from the slurry is generated by the bacterial decomposition of proteins containing sulfur amino acids (cysteine, methionine) under anaerobic conditions, and the bacterial reduction of sulfates. Due to its weight, $\mathrm{H}_{2} \mathrm{~S}$ accumulates at the bottom of slurry tanks and poses a threat to workers particularly during the work associated with cleaning of tanks. Long-term exposure to relatively low concentrations of $\mathrm{H}_{2} \mathrm{~S}$ (concentrations of $\mathrm{H}_{2} \mathrm{~S}$ below $30 \mathrm{ppb}$ contribute substantially to the formation of unpleasant odours), which can also occur in the case of people living in the vicinity of poorly designed slurry tanks, causes headaches and dizziness, irritation of eye mucosa and respiratory tract, as well as cough and nausea. At slightly higher concentrations, $\mathrm{H}_{2} \mathrm{~S}$ induces a range of ailments such as vomiting, respiratory system inflammation, impairment of smell, vision damage, as well as psychomotor disorders. Pulmonary oedema is a very common complication resulting from the exposure to hydrogen sulfide. At high concentrations, $\mathrm{H}_{2} \mathrm{~S}$ becomes undetectable due to the immediate damage to the olfactory nerve. Death occurs as a result of respiratory system paralysis. $\mathrm{H}_{2} \mathrm{~S}$ can also be dangerous for animals, especially in poorly ventilated buildings, where it can lead to pigs' death [44, 49-51].

The need to reduce emission of $\mathrm{H}_{2} \mathrm{~S}$ from pig slurry is dictated not only by a big odour nuisance of this gas but also by its strong toxicity. In order to ensure the safety of life and health of breeding farms' employees as well as animals Polish law defines the TLV of $\mathrm{H}_{2} \mathrm{~S}$ in the workplace, which is $7 \mathrm{mg} / \mathrm{m}^{3}$ during an 8-hour workday [48] and the maximum concentration of $\mathrm{H}_{2} \mathrm{~S}$ in facilities for pigs, which is $5 \mathrm{ppm}$ [22].

Odour nuisance of pig slurry can be reduced by the use of appropriate methods of pigs' feeding and rational ways of storing as well as applying of pig slurry. Good results in reducing emissions of odour, mainly $\mathrm{NH}_{3}$, are achieved by optimizing the composition of fodder, i.e. lowering the crude protein content and the addition of synthetic amino acids $[43,45,52,53]$. Portejoie et al. [54] proved that the reduction of crude protein content in the diet of fattening pigs from 20 to $12 \%$ caused a reduction of ammonia emissions from slurry by $63 \%$, from the moment it was produced to application onto the fields [54]. 
In livestock buildings with non-bedding system of pig farming the release of malodorous compounds from slurry can be limited thanks to shortening the time of its deposition in the open space, reduction of the exposed surface of slurry under grates, the use of ventilation techniques, which produce low air velocity around the slurry storage areas, avoiding high temperature in the piggery facilities, and the use of biofilters $[18,43$, $55,56]$.

The method, which effectively reduces the emission of odour-generating compounds from slurry during its storage is to keep it in sealed tanks equipped with airtight covers and mixing the slurry only before emptying the tank [8, 18, 43, 55]. Scotford and Williams [57] reported almost $100 \%$ reduction in $\mathrm{NH}_{3}$ emission from the slurry stored in a lagoon covered with a floating cover made of polyethylene [57]. Misselbrook et al. [58] demonstrated that covering the pig slurry with a layer of floating clay granules reduced $\mathrm{NH}_{3}$ emissions by $77 \%$ [58]. Matulaitis et al. [33] established that straw cover, sawdust cover and plastic film cover have a high reduction effect on $\mathrm{NH}_{3}$ emission from the stored pig slurry [33].

An increasingly common way to reduce odour emission from pig slurry is adding chemical substances (inorganic acids, calcium hydroxide, hydrogen peroxide), minerals (zeolites), rocks (peat), or biological preparations (plant extracts, specially selected enzymes or non-pathogenic microorganisms), which action consists in reducing the intensity of putrefactive fermentation processes, binding of volatile organic and inorganic compounds into stable chemical combinations, or changing the physicochemical properties of slurry $[18,55,59]$. Numerous scientific studies [43, 46, 60-64] indicate that acidification of pig slurry with sulfuric acid to a $\mathrm{pH}$ of about 5-6 significantly reduces the release of ammonia. Kai et al. [62] found that acidifying the slurry to a $\mathrm{pH}$ of 5.5 reduced the $\mathrm{NH}_{3}$ emission from livestock buildings by about $70 \%$, from the stored slurry by about $10 \%$, while from the slurry applied on the fields by about $67 \%$ in comparison to non-acidified pig slurry [62]. Furthermore, Dai and Blanes-Vidal [61] proved that lowering the $\mathrm{pH}$ of pig slurry to 5.5 by addition of sulfuric acid and its aeration reduced the $\mathrm{NH}_{3}$ emission from the stored slurry by about $77 \%$ compared to pig slurry not subjected to acidification and aeration [61]. However, due to the several risks associated with the use of sulfuric acid (foam formation during acid addition, corrosive effect of acid, strong acid which affects the health of farmers and animals) variant acidifying agents have been searched and tested [64, 65]. Regueiro et al. [65] stated that aluminum sulfate can be considered as a good alternative to $\mathrm{H}_{2} \mathrm{SO}_{4}$ when the $\mathrm{pH}$ of pig slurry is lowered to 5.5. The acidification of pig slurry to $\mathrm{pH} 5.5$ with $\mathrm{Al}_{2}\left(\mathrm{SO}_{4}\right)_{3}$ reduced ammonia volatilization during storage by $69 \%$ [65].

An environmentally friendly method of reducing the emission of odorants, especially phenolic ones (almost $100 \%$ reduction in the emission of $p$-cresol) from pig slurry is the use of minced horseradish roots or horseradish peroxidase in the presence of calcium peroxide or hydrogen peroxide [66-68]. Another environmentally friendly and low-cost method for odour removal from pig slurry involves the use of lignin peroxidase combined with peroxides $\left(\mathrm{CaO}_{2}\right.$ or $\left.2 \mathrm{Na}_{3} \mathrm{CO}_{3} \cdot 3 \mathrm{H}_{2} \mathrm{O}_{2}\right)$. Such pig slurry treatment reduces odour intensity by $40-60 \%$ and phenolic compounds by approximately $90 \%$ [69].

A good way to reduce odour emissions from pig slurry is its separation into solid and liquid fractions by the use of appropriately designed floors (separation of urine and faeces) [55], or by sedimentation, pressure filtration, sieving, drainage, or coagulation/flocculation processes $[70,71]$. 
In order to reduce the emission of odorants, especially $\mathrm{NH}_{3}$ (even to $99 \%$ ) from pig slurry, biological processes of nitrification and denitrification are also used. Nitrification takes place in two stages with the use of two genera of autotrophic bacteria. Nitrosomonas bacteria oxidize ammonia nitrogen to nitrate-nitrogen under aerobic conditions, afterwards Nitrobacter bacteria oxidize the nitrites to nitrates. As a result of denitrification, nitrates are reduced to molecular nitrogen and removed from the system to the atmosphere in the form of gas. The process of denitrification is carried out with heterotrophic bacteria under anaerobic conditions $[8,55,72]$.

Reducing the release of malodorous compounds, including $\mathrm{NH}_{3}$, from pig slurry, at the stage of its usage on cropland, can be achieved by choosing an appropriate application period, preferably on cool, moist and windless days, fertilizing with diluted slurry or a liquid fraction of slurry (reduction in slurry viscosity results in easier infiltration into the soil) and immediate (up to 6 hours) incorporation of slurry into the soil after its surface spreading onto agricultural land, or into-the-soil application of slurry [18, 46, 55, 73]. It is evident from the literature data [55] that direct injection of pig slurry into the soil reduces the emission of $\mathrm{NH}_{3}$ by $47-98 \%$ in comparison to its surface broadcasting. Moreover, the dilution of slurry can reduce the release of $\mathrm{NH}_{3}$ by 44-91\% [55]. Webb et al. [73] reported that the immediate incorporation of slurry into the soil using mouldboard plough, chisel plough, and disc harrow reduced the $\mathrm{NH}_{3}$ emission by 99,83 , and $90 \%$, respectively [73]. Sommer and Hutchings [46] stated that the incorporation of slurry into the soil one hour after its spreading on arable lands reduces the $\mathrm{NH}_{3}$ emissions by $80 \%$, whereas after six hours - by $45 \%$ [46]. The reduction of inconvenience associated with an unpleasant odour released during pig slurry spreading can also be promoted by the use of slurry tankers with applicators to band spreading of slurry (trailing hoses, trailing shoe) and the previously introduced cultivation of soil that is its proper loosening and aeration [18, $46,55,73$ ]. On the basis of the data presented by Ndegwa et al. [55] it can be concluded that the release of $\mathrm{NH}_{3}$ during the application of slurry using trailing hoses, trailing shoe, and shallow slot injection is about 39-83\% lower than the emission during the traditional distribution of pig slurry by surface broadcasting. According to the same literature data [55] cultivating soil before surface distribution of pig slurry reduces the $\mathrm{NH}_{3}$ losses by $40-90 \%$ in comparison to uncultivated soil [55].

\section{Conclusions}

Pig slurry is a valuable natural fertilizer and the most appropriate way of its management should be to fertilize arable land and grassland. In accordance with binding laws and regulations natural fertilizers, including slurry, can be applied in the period from 1 March to 30 November at the maximum dose not exceeding $170 \mathrm{~kg}$ N/ha per year. For this reason and due to the excessive formation of pig slurry in comparison to how much of it can be used in agriculture, pig slurry must be stored.

$\mathrm{NH}_{3}, \mathrm{H}_{2} \mathrm{~S}, \mathrm{CH}_{4}, \mathrm{CO}_{2}, \mathrm{~N}_{2} \mathrm{O}$ and other products of anaerobic fermentation are atmosphere polluting substances which are formed in significant quantities during storage and application of pig slurry onto soils. $\mathrm{NH}_{3}$ and $\mathrm{H}_{2} \mathrm{~S}$ are the most important odorants emitted from pig slurry as they may pose a great hazard for humans (odour nuisance, ailments of the respiratory system, death) and animals (susceptibility to infections and respiratory diseases, deaths). $\mathrm{NH}_{3}$ is also involved in the formation of acid rain and acidification of soils. $\mathrm{CH}_{4}, \mathrm{CO}_{2}$ and $\mathrm{N}_{2} \mathrm{O}$ contribute to climate change by increasing the 
greenhouse effect. $\mathrm{CO}_{2}$ has also an impact on health and productivity of pigs (metabolic disorders).

Considering the number of threats that can cause the emission of GHGs and odour-generating substances from pig slurry, especially in rural areas, there is an urgent need to undertake actions effectively limiting their release into the atmosphere. The reduction of the emission of GHGs and odorants from pig slurry can be achieved by proper feeding of pigs (feeding animals with fodder characterized by a reduced content of crude protein), proper storage of pig slurry (in sealed tanks, preferably at a temperature below $15{ }^{\circ} \mathrm{C}$, mixing the slurry just before emptying the tank), adequate management (acidification, separation into fractions, anaerobic fermentation, aeration) and reasonable usage on farmlands (choice of the appropriate equipment and period of application, surface application of pig slurry and its fast incorporation).

\section{References}

[1] Kwiecińska A, Konieczny K. Ecol Chem Eng A. 2013;20(2):239-249. DOI: 10.2428/ecea.2013.20(02)024.

[2] Marszałek M, Kowalski Z, Makara A. Technical Trans Chem. 2014;111:81-91. http://suw.biblos.pk.edu.pl/resourceDetailsRPK\&rId=49219.

[3] Sánchez M, González JL. Bioresour Technol. 2005;96:1117-1123. DOI: 10.1016/j.biortech.2004.10.002.

[4] Ustawa z dnia 10 lipca 2007 r. o nawozach i nawożeniu. Dz.U. 2007, Nr 147, poz. 1033. (Polish Act of 10 July 2007 on fertilizers and fertilization. J Laws 2007. No. 147. item 1033). http://prawo.sejm.gov.pl/isap.nsf/DocDetails.xsp?id=WDU20180001259.

[5] Obwieszczenie Ministra Rolnictwa i Rozwoju Wsi z dnia 17 lutego 2014 r. w sprawie ogłoszenia jednolitego tekstu rozporządzenia Ministra Rolnictwa i Rozwoju Wsi w sprawie szczegółowego sposobu stosowania nawozów oraz prowadzenia szkoleń z zakresu ich stosowania. Dz.U. 2014, poz. 393. (Public Notice of Minister of Agriculture and Rural Development of 17 February 2014 on consolidated text of the Regulation of the Minister of Agriculture and Rural Development on the detailed method of fertilizers application and conducting training in their use. J Laws Republic of Poland 2014. item 393). http://prawo.sejm.gov.pl/isap.nsf/DocDetails.xsp?id=WDU20140000393.

[6] Council Directive 91/676/EEC of 12 December 1991 concerning the protection of waters against pollution caused by nitrates from agricultural sources. Official J Europ Communities L 375. 31.12.1991. https://eurlex.europa.eu/legal-content/en/ALL/?uri=CELEX:31991L0676.

[7] Loyon L. Waste Manage. 2017;61:516-520. DOI: 10.1016/j.wasman.2016.11.040.

[8] Girard M, Nikiema J, Brzezinski R, Buelna G, Heitz M. Can J Civ Eng. 2009;36:1946-1957. DOI: 10.1139/L09-141.

[9] Cabaraux JF, Philippe FX, Laitat M, Canart B, Vandenheede M, Nicks B. Agr Ecosyst Environ. 2009;130:86-92. DOI: 10.1016/j.agee.2008.11.016.

[10] Martinez J, Guiziou F, Peu P, Gueutier V. Biosyst Eng. 2003;85(3):347-354. DOI: 10.1016/S15375110(03)00067-9.

[11] Kim KY, Ko HJ, Kim HT, Kim YS, Roh YM, Lee CM, et al. J Environ Manage. 2008;88:195-202. DOI: 10.1016/j.jenvman.2007.02.003.

[12] Blanes-Vidal V, Hansen MN, Adamsen APS, Feilberg A, Petersen SO, Jensen BB. Atmos Environ. 2009;43:2997-3005. DOI: 10.1016/j.atmosenv.2008.10.016.

[13] Schiffman SS, Bennett JL, Raymer JH. Agric Meteorol. 2001;108:213-240. DOI: 10.1016/S0168-1923(01)00239-8.

[14] Kim KY, Ko HJ, Kim HT, Kim YS, Roh YM, Lee CM, et al. Environ Monit Assess. 2007;133:255-266. DOI: 10.1007/s10661-006-9578-x.

[15] Viguria M, López DM, Arriaga H, Merino P. Water Air Soil Pollut. 2015;226:1-8. DOI: 10.1007/s11270-015-2548-6.

[16] Dennehy C, Lawlor PG, Jiang Y, Gardiner GE, Xie S, Nghiem LD, et al. Front Environ Sci Eng. 2017;11(3):1-16. DOI: 10.1007/s11783-017-0942-6.

[17] IPCC, 2014: Climate Change 2014: Synthesis Report. Contribution of Working Groups I, II and III to the Fifth Assessment Report of the Intergovernmental Panel on Climate Change [Core Writing Team, R.K. Pachauri and L.A. Meyer (eds.)]. IPCC, Geneva, Switzerland; 2014. http://www.ipcc.ch/pdf/assessmentreport/ar5/syr/SYR_AR5_FINAL_full_wcover.pdf. 
[18] Best Available Techniques (BAT) Reference Document for the Intensive Rearing of Poultry or Pigs. Industrial Emissions Directive 2010/75/EU (Integrated Pollution Prevention and Control). Luxembourg: Publications Office of the European Union; 2017. DOI: 10.2760/020485.

[19] Sommer SG, Petersen SO, Sørensen P, Poulsen HD, Møller HB. Nutr Cycl Agroecosyst. 2007;78:27-36. DOI: $10.1007 / \mathrm{s} 10705-006-9072-4$.

[20] Philippe FX, Nicks B. Agr Ecosyst Environ. 2015;199:10-25. DOI: 10.1016/j.agee.2014.08.015.

[21] Møller HB, Sommer SG, Ahring BK. J Environ Qual. 2004;33:27-36. DOI: 10.2134/jeq2004.2700.

[22] Rozporządzenie Ministra Rolnictwa i Rozwoju Wsi z dnia 15 lutego 2010 r. w sprawie wymagań i sposobu postępowania przy utrzymywaniu gatunków zwierząt gospodarskich, dla których normy ochrony zostały określone w przepisach Unii Europejskiej. Dz.U. 2010, Nr 56, poz. 344. (Regulation of Minister of Agriculture and Rural Development of 15 February 2010 on the requirements and the manner of keeping of farm animal species for which protection standards are laid down in the provisions of the European Union. J Laws 2010. No 56. item 344). http://prawo.sejm.gov.pl/isap.nsf/DocDetails.xsp?id=WDU20100560344.

[23] Ni JQ, Hendriks J, Coenegrachts J, Vinckier C. Atmos Environ. 1999;33:3691-3696. DOI: 10.1016/S1352-2310(99)00127-2.

[24] Berg W, Brunsch R, Pazsiczki I. Agr Ecosyst Environ. 2006;112:129-134. DOI: 10.1016/j.agee.2005.08.031.

[25] Haeussermann A, Hartung E, Gallmann E, Jungbluth T. Agr Ecosyst Environ. 2006;112:115-121. DOI: 10.1016/j.agee.2005.08.011

[26] Thomson AJ, Giannopoulos G, Pretty J, Baggs EM, Richardson DJ. Philos T Roy Soc B. 2012;367:1157-1168. DOI: 10.1098/rstb.2011.0415.

[27] Severin M, Fuss R, Well R, Garlipp F, Van den Weghe H. Plant Soil Environ. 2015;61(8):344-351. DOI: 10.17221/21/2015-PSE.

[28] Bálint Á, Hoffmann S, Anton A, Szili-Kovács T, Heltai G. Ecol Chem Eng S. 2013;20(2):233-245. DOI: 10.2478/eces-2013-0016.

[29] Chadwick D, Sommer S, Thorman R, Fangueiro D, Cardenas L, Amon B, et al. Anim Feed Sci Tech. 2011;166-167:514-531. DOI: 10.1016/j.anifeedsci.2011.04.036.

[30] Loyon L, Guiziou F, Beline F, Peu P. Int Congr Ser. 2006;1293:299-302. DOI: 10.1016/j.ics.2006.02.017.

[31] Decision No 406/2009/EC of The European Parliament and of The Council of 23 April 2009 on the effort of Member States to reduce their greenhouse gas emissions to meet the Community's greenhouse gas emission reduction commitments up to 2020. https://eur-lex.europa.eu/legal-content/EN/TXT/ ?uri=uriserv:OJ.L_.2009.140.01.0136.01.ENG.

[32] Fangueiro D, Ribeiro H, Coutinho J, Cardenas L, Trindade H, Cunha-Queda C, et al. Biol Fertil Soils. 2010;46:383-391. DOI: 10.1007/s00374-010-0444-1.

[33] Matulaitis R, Juškienė V, Juška R. Chilean J. Agric Res. 2015;75(2):232-238. DOI: 10.4067/S0718-58392015000200013.

[34] Thomsen IK, Pedersen AR, Nyord T, Petersen SO. Agr Ecosyst Environ. 2010;136:227-235. DOI: 10.1016/j.agee.2009.12.001.

[35] Bertora C, Alluvione F, Zavattaro L, van Groenigen JW, Velthof G, Grignani C. Soil Biol Biochem. 2008;40:1999-2006. DOI: 10.1016/j.soilbio.2008.03.021.

[36] Lovanh N, Warren J, Sistani K. Bioresour Technol. 2010;101:1662-1667. DOI: 10.1016/j.biortech.2009.09.078.

[37] Lo Y-CM, Koziel JA, Cai L, Hoff SJ, Jenks WS, Xin H. J Environ Qual. 2008;37:521-534. DOI: $10.2134 /$ jeq2006.0382.

[38] Zhu J. Agr Ecosyst Environ. 2000;78:93-106. DOI: 10.1016/S0167-8809(99)00116-4.

[39] Blanes-Vidal V, Hansen MN, Adamsen APS, Feilberg A, Petersen SO, Jensen BB. Atmos Environ. 2009;43:3006-3014. DOI: 10.1016/j.atmosenv.2009.01.046.

[40] Hobbs PJ, Misselbrook TH, Pain BF. J Sci Food Agric. 1998;77:341-348. DOI: 10.1002/(SICI)1097-0010(199807)77:3<341::AID-JSFA45>3.0.CO;2-9.

[41] Philippe FX, Cabaraux JF, Nicks B. Agr Ecosyst Environ. 2011;141:245-260. DOI: 10.1016/j.agee.2011.03.012.

[42] Xu Y-Y, Guan J-N. Ecol Chem Eng S. 2014;21(1):71-77. DOI: 10.2478/eces-2014-0006.

[43] Arogo J, Westerman PW, Heber AJ, Robarge WP, Classen, JJ. Ammonia Emissions from Animal Feeding Operations. National Center for Manure and Animal Waste Management White Papers. North Carolina State University. Raleigh, NC; 2002. http://citeseerx.ist.psu.edu/viewdoc/ download?doi=10.1.1.484.8060\&rep=rep1\&type=pdf.

[44] Yokoyama MT, Park S, Chou KC, Bursian SJ. Comprehensive review on human health effects of pork production emissions - NPB\# 00-173. Research Report. Michigan State University; 2003. https://www.pork.org/wp-content/uploads/2007/07/00-173-YOKOYAMA-MICHST.pdf. 
[45] Webb J, Broomfield M, Jones S, Donovan B. Sci Total Environ. 2014;470-471:865-875. DOI: 10.1016/j.scitotenv.2013.09.091.

[46] Sommer SG, Hutchings NJ. Eur J Agron. 2001;15:1-15. DOI: 10.1016/S1161-0301(01)00112-5.

[47] The National Centre for Emissions Management (KOBiZE). National emission balance of $\mathrm{SO}_{2}, \mathrm{NO}_{\mathrm{X}}, \mathrm{CO}_{\text {, }}$ $\mathrm{NH}_{3}$, NMVOC, particulate matter, heavy metals and POPs for the years 2011-2012 in the SNAP classification system. Synthesis Report; 2014. http://www.kobize.pl.

[48] Rozporządzenie Ministra Rodziny, Pracy i Polityki Społecznej z dnia 12 czerwca 2018 r. w sprawie najwyższych dopuszczalnych stężeń i natężeń czynników szkodliwych dla zdrowia w środowisku pracy. Dz.U. 2018, poz. 1286. (Regulation of Minister of Labour and Social Policy of 12 June 2018 on workplace exposure limits. J Laws 2018. item 1286). http://prawo.sejm.gov.pl/isap.nsf/DocDetails.xsp?id=WDU20180001286.

[49] Predicala B, Nemati M, Stade S, Lagu C. J Hazard Mater. 2008;154:300-309. DOI: 10.1016/j.jhazmat.2007.10.026.

[50] Rumsey IC, Aneja VP. Environ Sci Technol. 2014;48:1609-1617. DOI: 10.1021/es403716w.

[51] Banhazi T, Aland A, Hartung J. Air Quality and Livestock Farming. London: CRC Press; 2018.

[52] Dourmad JY, Jondreville C. Livest Sci. 2007;112:192-198. DOI: 10.1016/j.livsci.2007.09.002.

[53] Hobbs PJ, Pain BF, Kay RM, Lee PA. J Sci Food Agr. 1996;71:508-514. DOI: 10.1002/(SICI)1097-0010(199608)71:4<508::AID-JSFA610>3.0.CO;2-0.

[54] Portejoie S, Dourmad JY, Martinez J, Lebreton Y. Livest Prod Sci. 2004;91:45-55. DOI: 10.1016/j.livprodsci.2004.06.013.

[55] Ndegwa PM, Hristov AN, Arogo J, Sheffield RE. Biosyst Eng. 2008;100:453-469. DOI: 10.1016/j.biosystemseng.2008.05.010.

[56] Portejoie S, Martinez J, Guiziou F, Coste CM. Bioresour Technol. 2003;87:199-207. DOI: 10.1016/S0960-8524(02)00260-2.

[57] Scotford IM, Williams AG. J Agr Eng Res. 2001;80:273-281. DOI: 10.1006/jaer.2001.0744.

[58] Misselbrook T, Hunt J, Perazzolo F, Provolo G. J Environ Qual. 2016;45:1520-1530. DOI: 10.2134/jeq2015.12.0618.

[59] McCrory DF, Hobbs PJ. J Environ Qual. 2001;30:345-355. DOI: 10.2134/jeq2001.302345x.

[60] Eriksen J, Sorensen P, Elsgaard L. J Environ Qual. 2008;37:280-286. DOI: 10.2134/jeq2007.0317.

[61] Dai XR, Blanes-Vidal V. J Environ Manage. 2013;115:147-154. DOI: 10.1016/j.jenvman.2012.11.019.

[62] Kai P, Pedersen P, Jensen JE, Hansen MN, Sommer SG. Eur J Agron. 2008;28:148-154. DOI: 10.1016/j.eja.2007.06.004.

[63] Fangueiro D, Gusmão M, Surgy S, Cabral F. Assessment of $\mathrm{CO}_{2}$ emissions during acidification, storage, and after incorporation to soil of pig slurry. Proceedings of $14^{\text {th }}$ RAMIRAN Conference 13-15 September 2010. Lisboa, Portugal, 2010:276-279. http://ramiran.uvlf.sk/ramiran2010/docs/Ramiran2010_0314_final.pdf.

[64] Fangueiro D, Hjorth M, Gioelli F. J Environ Manage. 2015;149:46-56. DOI: 10.1016/j.jenvman.2014.10.001.

[65] Regueiro I, Coutinho J, Fangueiro D. J Clean Prod. 2016;131:296-307. DOI: 10.1016/j.jclepro.2016.05.032.

[66] Govere EM, Tonegawa M, Bruns MA, Wheeler EF, Heinemann PH, Kephart KB, et al. J Agric Food Chem. 2005:53:4880-4889. DOI: 10.1021/jf0404290.

[67] Govere EM, Tonegawa M, Bruns MA, Wheeler EF, Kephart KB, Voigt JW, et al. Bioresour Technol. 2007;98:1191-1198. DOI: 10.1016/j.biortech.2006.05.012.

[68] Ye FX, Zhu RF, Li Y. J Hazard Mater. 2009;167:148-153. DOI: 10.1016/j.jhazmat.2008.12.096.

[69] Yan Z, Wei X, Yuan Y, Li Z, Li D, Liu X, et al. J Air Waste Manage. 2016;66(4):420-428. DOI: 10.1080/10962247.2016.1144660.

[70] Ndegwa PM, Zhu J, Luo A. Biosyst Eng. 2002;81(1):127-133. DOI: 10.1006/bioe.2001.0008.

[71] Hjorth M, Christensen KV, Christensen ML, Sommer SG. Agron Sustain Dev. 2010;30:153-1801. DOI: 10.1051/agro/2009010.

[72] Loughrin JH, Szogi AA, Vanotti MB. Appl Eng Agric. 2006;22(6):867-873. DOI: 10.13031/2013.22258.

[73] Webb J, Pain B, Bittman S, Morgan J. Agr Ecosyst Environ. 2010;137:39-46. DOI: 10.1016/j.agee.2010.01.001. 